\title{
内接形トロコイドギヤポンプのマイクロ化に向けた実験的研究*
}

\author{
宮 城 直 樹*1, 村 井 祐 一*2 \\ 宮 㠃 孝 司*3, 山本 富士 夫*4
}

\section{Experimental Study of an Inscribed Trochoid Gear Pump for Miniaturization}

\author{
Naoki MIYAGI, Yuichi MURAI*5, \\ Koji MIYAZAKI and Fujio YAMAMOTO \\ ${ }^{* 5}$ Division of Energy and Environmental System, Graduate School of Engineering, Hokkaido University, \\ N 13 W 8 Kita-ku, Sapporo-shi, Hokkaido, 060-8628 Japan
}

\begin{abstract}
The pumping characteristics of an inscribed trochoid gear pump are investigated experimentally. The paper deals with viscosity-dominant conditions, i.e. low Reynolds number performances less than 5000 in order to develop a miniaturized pump. The test pump of $4 \mathrm{~mm}$ in the inner basic radius is designed for the experimentation. The volume flow rate and the pressure rise of the pump are measured using a test loop with two different liquids. Volumetric efficiency, dimensionless pressure rise, and pump's power efficiency are obtained as function of Reynolds number. The present results support the previous theoretical study, that is, the lower Reynolds number the higher performance the trochoid gear pump has. This implies an advantage toward miniaturization. On the other hand; the pump's power efficiency is obtained as only a few \% because of significant increment of wear caused in six parts of gear clearance, which should be discussed as the next step of the research.
\end{abstract}

Key Words: Hydromachinery, Pump, Trochoid Gear, Computational Fluid Dynamics, Moving Boundary Problem, Three-Dimensional Flow

\section{1. 緒論}

トロコイドギヤポンプはトロコイド曲線を組合せて 設計された二つのギアによる容積形ポンプである。こ のうち内接形トロコイドギヤポンプは同じギヤ基底円 で比較すると外接形よりも小形化が可能であり，この ため医療技術，電子デバイス冷却などの分野において 応用が期待されている。ポンプを小形化するとポンプ 性能は必然的に低レイノルズ数域での内部流動に支配 される，著者らは既報(1)において，レイノルズ数が $1 \sim 10^{3}$ の範囲での内部流動を三次元数值解析し，レイ ノルズ数が約 10 のときにポンプ効率が最大となるこ とを明らかにした。このことは粘性が必ずしもエネル ギーの損失ばかりを導くわけではなく，トロコイドギ ヤの流体駆動原理においては粘性を活用するという側 面をもっていることを意味する，具体的には，ギヤ表 面での粘性せん断応力が流体を順方向に駆動させるこ

* 原稿受付 2005 年 5 月 17 日.

*1 正員, MATプレロマ(株)(业226-0017 横浜市緑区新治町 571-3).

*2 正員, 北海道大学工学研究科 ( 060-8628 札幌市北区北 13 条西 8).

*3 福井県産業労働部 ( 910-8580 福井市大手 3-17-1).

*4 正員, 福井大学工学研究科 ( 3 910-8507 福井市文京 3-9-1).

E-mail : murai@eng.hokudai.ac.jp
と,および, ギヤクリアランス部を漏れる流量が粘性 によって抑制され昇圧が保たれることが数值解析によ ってそれぞれ明らかとなった。低レイノルズ数におけ るこのような特性は, ポンプのマイクロ化にも適して いるといえる。

一方，一般の容積形ポンプ(ピストン, プランジャ, スクリュー, ベーン, スクロールなど)の特性は, 容積 効率のみが評価されることが多い。これは, 圧力負荷 の変動に対して流量がほほ一定であり,この結果, 動 力効率 (ポンプ全効率)が主として容積効率に支配され るためである ${ }^{(2)(3)}$. 一方, 容積形ポンプを小形化する と, 与える軸動力に対してしゅう動部での摩擦損失が 無視できなくなり, 動力効率の低下が問題となる.す なわち，ポンプ容積に対するしゅう動部の面積割合が 大きい場合では, しゅう動部のクラアランスを小さく するほど容積効率の保持が実現するものの, これと同 時に動力効率が低下するという相反関係が生じる. ト ロコイドギヤポンプの場合では六つのしゅう動部(詳 細は後述)があり, 小形化に伴って上述のような性質 が生じると考えられる.このことはモー夕を含めたポ ンプ全体の小形化において現時点での重要な課題(4)(5) となっている.

そこで本研究ではレイノルズ数が 5000 以下の条件 
を対象として，ミニチュアトロコイドギヤポンプモデ ルによる試験装置を製作し, 容積効率と動力効率の双 方を計測した。本報ではそれらの試験方法, 結果なら びに考察について述べる。

\section{2. 実 験 装 置}

\section{$2 \cdot 1$ トロコイドギヤの定義形状図 1 に本研究} で扱う内接形トロコイドギヤポンプの概形を示す。内 側ギヤは中心 $O_{1}$ を軸に, 外側ギヤは中心 $O_{2}$ を軸に, ともに時間回りに回転する，流体はこれらの二つのギ ヤと二つの静止平行壁面によって封入される。モータ は内側ギヤの回転を駆動し, 外側ギヤは内側ギヤとの かみ合わせにより従動する.内側ギヤ歯数を $k$ とす るとき外側ギヤ歯数は $k+1$ である. 内側ギヤ形状は, 式 (1)によるサイクロイド曲線で定義される.サイク ロイド曲線は, トロコイド曲線の一つの形であり, 転 円の中心が一定半径上を移動するという特徴がある.

$$
\left(\begin{array}{l}
x \\
y
\end{array}\right)=(a+b)\left(\begin{array}{l}
\cos \theta \\
\sin \theta
\end{array}\right)-b\left\{\begin{array}{l}
\cos (1+a / b) \theta \\
\sin (1+a / b) \theta
\end{array}\right\} .
$$

ここで, $(x, y)$ は回転軸を原点とする歯面の座標, $\theta$ は角度, $a$ と $b$ はギヤ基底半径(導円)とサイクロイド 半径である。 $a / b$ は $2 k$ に一致させる。外転サイクロ イド曲線は式( 1 )を $b>0$ の条件で, 内転サイクロイ ド曲線は $b<0$ の条件で適用したもので, 転円が一周 するごとに $b$ の符号を反転させることで, トロコイド ギヤの歯面形状が表現される.なお $k$ が小さいほど 基底円面積 $\pi a^{2}$ に対して流体封入面積が大きく確保 され，マイクロ化に適する，ただし $k<4$ のとは外 側ギヤ歯面の最大半径位置が基底半径 $a$ の 2 倍以上 となりトルク変動振幅が急増する.このようなバラン スから本研究では $k=4$ を選定した。

トロコイドギヤポンプのしゅう動部は六つの面から なる、まず，内側ギヤと外側ギヤがそれぞれ $z$ 方向 (図 1 参照)の両端に合計 4 面のしゅう動面がある.こ れらのしゅう動面では固体摩擦接触によってギヤが停 止しないよう一定のクリアランス $\delta$ が設けられる。 内部にも流体が浸透し, 粘性せん断応力によるトルク 負荷をもたらす. 外側ギヤはその外周において円筒状 のしゅう動面が一つある。ここでも同様にクリアラン ス $\delta$ が設けられ, 流体によるトルク負荷が生じる.内 側ギヤと外側ギヤが接触する部分は, 固体接触点の一 つであるがここでは流体を仕切る効果があるが両ギヤ 間で相対速度はなく, 摩擦によるトルク負荷は生じな い. 一方, 理論的には固体接触点の反対側に両ギヤ間 で相対速度をもつ接触点が存在するが，実際にはギヤ かみ合わせに対するクリアランス $\varepsilon$ (図 1 参照)が設け

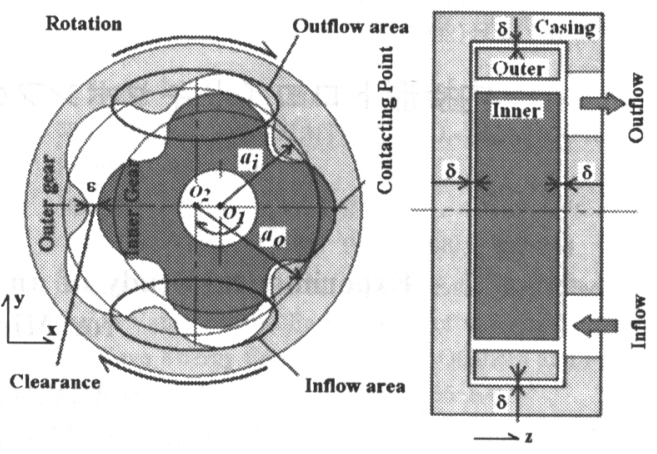

Fig. 1 Configuration of a Trochoid gear pump

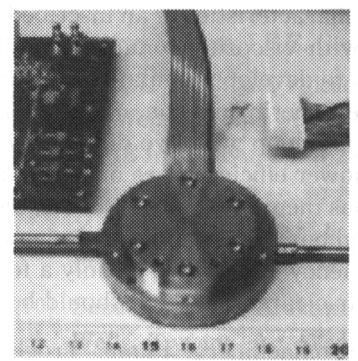

(a) Overview of pump body

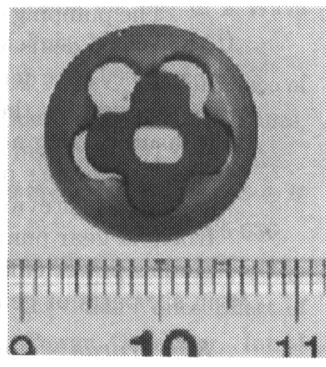

(b) Gear parts
Fig. 2 Miniturized experimental model

られ，固体摩擦を伴わずに滑らかに回転する，クラア ランス $\varepsilon$ は固体接触を回避するために必要不可欠で あるが, 実際にはギヤ表面の摩擦等によって自然に発 生し拡大する性質がある。したがってクリアランス は他のしゅう動部のクリアランス $\delta$ とは異なり不可 制御因子である。

$2 \cdot 2$ 性能試験装置および実験条件図 2(a), (b)に本研究用に製作した小形卜ロコイドギヤポンプ の写真を示す。ポンプ本体はモータロータ(マグネッ ト)が内蔵されたキャンド形でありケーシングを含め て直径 $40 \mathrm{~mm}$, 厚さ $15 \mathrm{~mm}$ である.ギヤ部は高耐食 性, 低しゅう動摩擦と高耐久性を実現するためにカー ボン系素材を用い, 内側ギヤの基底円半径を $a_{i}=4$ $\mathrm{mm}$ とした. 内外ギヤの幾何学的パラメータの詳細 は表 1 のと扔りである. 実験上の制御因子は内側ギヤ 回転数 $n$ と差圧を変化させるためのバルブ開度 $v$ の 二つである.これに対して計測因子は体積流量 $Q$ と 差压 $P$ である。これらは以下の無次元数で整理され る.

$$
\operatorname{Re}=\frac{U D}{\nu}=\frac{\omega D^{2}}{2 \nu}=\frac{\pi n D^{2}}{60 \nu}
$$


Table 1 Dimensionless specification of trochoid gear pump tested

\begin{tabular}{|l|l|l|c|}
\hline \multirow{4}{*}{$\begin{array}{l}\text { Inner } \\
\text { Gear }\end{array}$} & Gear number & $k$ & 4 \\
\cline { 2 - 4 } & Base radius & $a_{i}$ & 1.00 \\
\cline { 2 - 4 } & Ratio of cycloid radius & $e_{i}$ & 0.60 \\
\cline { 2 - 4 } & Inner cycloid radius & $b_{l i} / a_{i}$ & 0.15 \\
\cline { 2 - 4 } & Outer cycloid radius & $b_{2 i} / a_{i}$ & 0.10 \\
\hline \multirow{4}{*}{$\begin{array}{l}\text { Outer } \\
\text { Gear }\end{array}$} & Gear number & $k+1$ & 5 \\
\cline { 2 - 4 } & Base radius & $a_{o}$ & 1.25 \\
\cline { 2 - 4 } & Ratio of cycloid radius & $e_{o}$ & 0.60 \\
\cline { 2 - 4 } & Inner cycloid radius & $b_{10} / a_{o}$ & 0.12 \\
\cline { 2 - 4 } & Outer cycloid radius & $b_{20} / a_{o}$ & 0.08 \\
\hline Clearance & $\varepsilon / a_{i}$ & 0.05 \\
\hline \multicolumn{2}{|l|}{ Spanwise depth (aspect ratio) } & $W / a_{i}$ & 0.50 \\
\hline \multicolumn{2}{|l|}{ Reynolds number } & $R e$ & Up to 5000 \\
\hline
\end{tabular}

(all parameters are normalized with inner gear base radius )

$$
\begin{array}{r}
H^{*}=\frac{P}{\rho U^{2}}=P\left(\frac{\rho D^{2} \omega^{2}}{4}\right)^{-1}=P\left\{\rho D^{2}\left(\frac{\pi n}{60}\right)^{2}\right\}^{-1} \\
\cdots \cdots \cdots \cdots(3) \cdots \cdots \cdots \cdots \cdots(4)
\end{array}
$$

ここで $D$ は内側ギヤ基底円直径 $\left(D=2 a_{i}\right), U=$ $\omega(D / 2)$ は内側ギヤの基底円半径上のギヤ周速度, $\omega$ は内側ギヤの角速度, $\rho$ は流体の密度, $\nu$ は流体の動

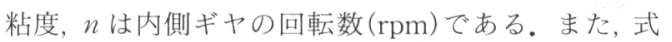
(4)の $V_{0}$ と $V_{i}$ はそれぞれ外側ギヤおよび内側ギヤ 歯面の内包体積, $\omega$ は内側ギヤの角速度である. 式 (4)の $Q_{0}$ は, トロコイドギヤポンプにおける流体封 入体積と周波数の積で与えられる基準流量である.こ の基準流量は, 不確定要因であるクリアランス $\varepsilon$ や流 体の出入口ポートの位置に依存しないため, データ整 理上, 少ない因子で記述されるという意味で都合がよ い.これに対してトロコイドギヤポンプの厳密な意味 での理論流量は解析的に簡単に与えられない. 寸なわ ち理論流量は，二つのトロコイドギヤの間に形成され る流体密閉室のうち最大体積をもつ瞬間の密閉室の体 積に，それが実現する周波数を乗じたものである。こ の最大体積は, 式 (1)を数值積分しなければ算定され ず, かつ, 流体の出入口ポートの位置・形状にも支配 される.上述の理由から, 式（4)では基準流量 $Q_{0}$ を 用いる。

図 3 にポンプ性能試験装置の概略図を, 図 4 に実物 の外観写真を示す。粘度の違いがポンプ特性に及ぼす 影響を調べるため, 作動流体にはメタノールと純水の 2 種類を用い, またそれらの温度管理にも注意を払っ た. 作動流体は図 3 の黒く示された閉ループを循環 し, チラーにより冷媒温度を設定し熱的平衡状態まで

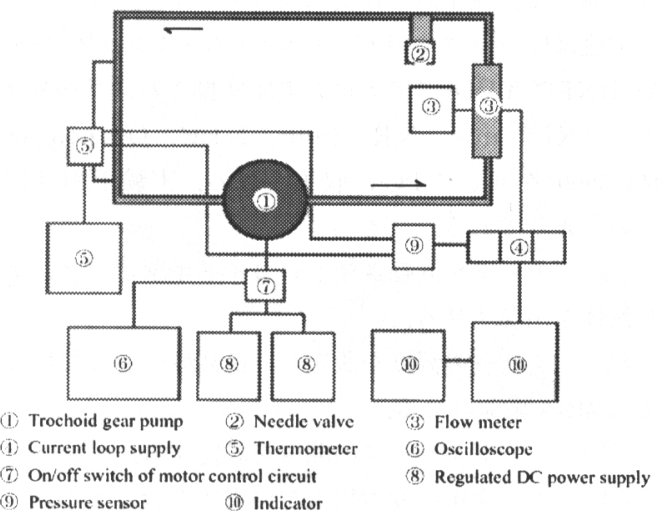

Fig. 3 Schematic diagram of pump performance test loop

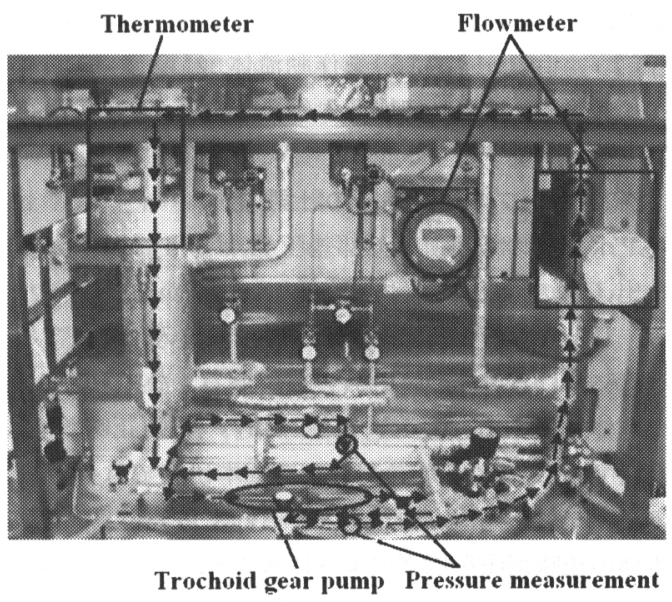

Fig. 4 Photograph of the test loop

待つことで, $5,20,40^{\circ} \mathrm{C}$ 三つの温度条件による試験 を実施した。これらの温度においてメタノールは純水 に対して動粘度が 0.70 倍 $\left(5^{\circ} \mathrm{C}\right), 0.82$ 倍 $\left(20^{\circ} \mathrm{C}\right), 0.98$ 倍 $\left(40^{\circ} \mathrm{C}\right)$ である. 回路用直流定電圧電源(菊水製, $\mathrm{PMC} 18-3$, 出力 $0 \sim 18 \mathrm{~V}, 0 \sim 3 \mathrm{~A}$ ) の電圧を $5 \mathrm{~V}$ (一 定)に設定し, モータ電圧変調用電源 (Kenwood 製, PS 20-18, 出力 $0 \sim 20 \mathrm{~V}, 0 \sim 18$ A) の電圧を変化させ ることにより, 内側ギヤの回転数 $n$ を $0 \sim 2500 \mathrm{rpm}$ の範囲で制御する. 正確な回転数 $n$ は電圧信号を才 シロスコープ(Hewlett Packard 製, 54201 D)で計測 することで得られる。 また, 流路内に取付けたニード ルバルブの開度を 6 段階に変化させ, ループの流動抵 抗すなわちポンプ差圧負荷を設定する. 吐出し流量 $Q$ はループ内に取付けた流量計により, 外部差圧 $P_{o}$ (これに対して正味差圧 $P$ にいては $2 \cdot 3$ 節で述べ る)はポンプ前後に配置された二つの圧力センサによ 
り計測する．流量計と圧力センサからの信号(アナロ グ電流) は，ディストリビュータ(エム・システム技研, M-UNIT, YVD) でアナログ電圧変換され，データロ ガー (Keyence, NR-2000, NEC, Omniace, RT 3600)を通して PCに収集される。実験手順は以 下のとおりである。

（1）モータを回転させトロコイドギヤポンプによ り液体を循環させる.

（2）チラーの温度を設定し, 液温が一定になるま で, 流体を循環させる。

（３） ニードルバルブの開度を設定する.

（4）モー夕電圧変調用電源の電圧を設定する.

（5）オシロスコープ, 温度計, データロガーから 回転数, 温度, 吐出し流量を取得する.

(6) 手順 $(1) \sim(5)$ を回転数 $n$ を変化させて繰 返す.

（7）手順（1)〜（6) を作動流体,. 温度, ニードル バルブ開度を変更して繰返す (総計 36 セットの実験を 実施).

$2 \cdot 3$ ポンプの正味差圧の計測方法 トロコイド ギヤポンプに作用する外部差圧 $P_{0}$ は図 4 に示すよう な出入口の導管に取付けた圧力センサから計測され る.しかしながら圧力センサからギヤ出入口部までの 導管における流体の圧力損失が無視できないため, ギ ヤ本体 [図 2(b)の部分] が作り出す昇圧(正味差圧) $P$ よりもつね低く計測される。本研究では導管で の圧力損失を構造上の外的因子として位置付け, ギャ 本体の正味差圧を以下のように求める.

$$
P=P_{0}+\left\{\sum_{i=1}^{N} \lambda_{i} \frac{l_{i}}{d_{i}} \frac{1}{2} \rho u_{i}^{2}+\sum_{i=1}^{M} \zeta_{i} \frac{1}{2} \rho u_{i}^{2}\right\} \cdots \cdots(5)
$$

ここで添字 $i$ は各管路における值であり, $\lambda$ は管摩 擦係数, $d$ は管直径, $l$ は管長, $u$ は管内平均流速, $\zeta$ は管路の幾何学的変化(曲がり, 拡大, 縮小)による損 失係数である.実験に用いたポンプの導管の経路は複 数の部分から構成され, 式(5)において本ポンプでは 管路数が $N=5$, 管路変形部が $M=4$ であった。なお 管路内のレイノルズ数は 0〜5000であり, 以下の管摩 擦係数 $\lambda$ と損失係数 $ら$ 式を利用した。

【直管の管摩擦係数】

$$
\begin{aligned}
& \lambda=\frac{64}{R e_{d}}\left(\operatorname{Re}_{d}<3000\right), \operatorname{Re}_{d}=\frac{u d}{\nu} \\
& \lambda=0.3164 \operatorname{Re}_{d}^{-0.237}\left(\operatorname{Re}_{d}>3000\right) \cdots
\end{aligned}
$$

【曲がり管の損失係数】

$$
\begin{aligned}
& \zeta_{b}=0.00873 \alpha \lambda_{c}\left(2 R_{c} / d\right) \theta \\
& \alpha=0.95+17.5\left(2 R_{c} / d\right)^{-1.96} \\
& \lambda=0.316\left(2 R_{c} / d\right)^{-0.1} \operatorname{Re}_{d}^{-0.2}
\end{aligned}
$$

【拡大管の損失係数】

$$
\zeta_{d}=\left\{1-\left(d_{2} / d_{1}\right) 2\right\}^{2}
$$

\section{【縮小管の損失係数】}

$$
\zeta_{c}=(1 / C-1)^{2}, C=f\left(d_{2} / d_{1}\right)
$$

式( 8$) \sim(10) に お い て ~ R_{c}$ は曲率半径, $\theta$ は曲がり 角 $\left(^{\circ}\right), d_{2} / d_{1}$ は管直径比である.式(12)の $C$ は実験 值 $\left.{ }^{6}\right)$ を適用する。なお式 $(5)$ ( 12$)$ による導管での 圧力損失 $\left(P-P_{o}\right)$ は本研究の実験範囲において正味差 圧 $P$ の 2 10\%の範囲であったすなおち正味差圧 $P$ に対する計測誤差は最大でも $10 \%$ 程度であるとい える.

$2 \cdot 4$ ポンプの容積効率と動力効率 $\quad 2 \cdot 2$ 節で述 ベたように, トロコイドギヤポンプの正確な理論流量 が与えられていないため, ポンプの容積効率の正確な 値を算定することができない.ここでは式 (4)の無次 元流量に近いとして以下ではいったん， $Q^{*}$ を容積効 率として評価する.なお $3 \cdot 5$ 節で述べるとおり実験結 果からの推測では容積効率は $Q^{*}$ を 1.2 で除した程度 の值をもつ. 次に，ポンプが流体に与えた単位時間あ たりのエネルギー, すなわち正味動力は, 次式によっ て与えられる。

$$
L=P Q=H^{*} Q^{*}\left(\rho U^{2} Q_{0}\right)
$$

容積効率が $100 \%$ でしゅう動部での動力損失がいつ さいないような理想的な容積形ポンプの場合, モータ から与えられる軸動力はそのまま比例して正味差圧 $P$ に反映される。これに対して現実のトロコイドギ ヤポンプではギヤにクリアランスが必要であり, 使用 する環境の差圧が大きいほど $Q^{*}$ が低下する。またし ゆう動部の摩擦はポンプが小形であるほど全体の動力 に対する影響が増大し，正味差圧の低下を招く．本研 究ではモータから与えられる軸動力に対する動力効率 を次式で定義する。

$$
\eta=\frac{L}{L_{a}}=H^{*} Q^{*}\left(\frac{\rho U^{2} Q_{0}}{L_{a}}\right)
$$

ここで軸動力 $L_{a}$ は, 電圧 $\times$ 電流の值で計測され る.

\section{3. 実 験 結 果}

$3 \cdot 1$ 流量と回転数の関係および粘性の影響 図 5 に, メタノールと水の 2 種類の液体を対象としたポ ンプ流量特性の計測結果を示す。この実験条件は実験 ループにおいて意図的な差圧負荷を与えない条件，す なわちバルブ開度 $100 \%$ の条件である，ただし $2 \cdot 3$ 節 で述べたとおり，正味差圧はループおよび導管等の圧 損によって存在することを断っておく．すなわち完全 な無負荷条件ではなく“小”負荷条件である，回転数 


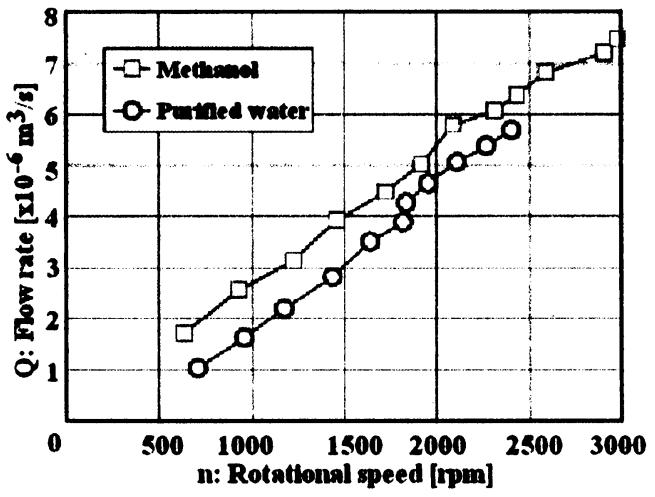

Fig. 5 Flow rate as function of rotational speed

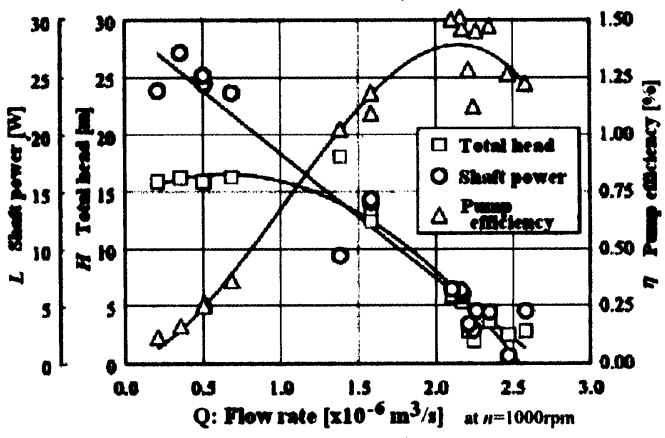

Fig. 6 Pump performance at $n=1000 \mathrm{rpm}$

$n$ は内側ギヤの回転数であり, 外側ギヤのそれは歯数 比に従って $n$ の 4/5 倍である. 図 5 より負荷が小さ い場合では回転数 $n$ の増加に対して流量はほほ線形 的に増大することが確認できる，一方，粘度の小さい メタノールのほうが純水に比べ流量が 5 40\%大き い.このことは一見, 粘性がポンプ性能を悪化させる かのように解釈できる。この結果は, 数值解析結果 ${ }^{(1)}$ ならびに序論で述べた粘性の積極的な寄与と矛盾す る.しかし実際の原因は, 粘度の小さいメタノールの ほうが実験ループの圧損が小さいことにある.ポンプ 本体の機構に起因する性能は，この計測結果からだけ では不明である。このように容積形ポンプとはいえ, 差圧に留意しないで流量だけを調べた場合，ポンプ本 来の性能を誤って解釈しやすい. 特段, 小形ポンプの 場合には，粘性がポンプ入口と出口の間の差圧を支配 するため, 差圧の計測を含めた分析が不可欠である.

$3 \cdot 2$ 正味差圧と動力効率 図 6 に横軸は実次元 の流量 $Q$, 綐軸は正味差圧 $H$ ( $\square$ 印), 軸動力 $L(\bigcirc$ 印), 動力効率 $\eta$ ( $\triangle$ 印) の計測結果を示す.これらの 実験点はすべて回転数が $n=1000 \mathrm{rpm}$ の条件のもの

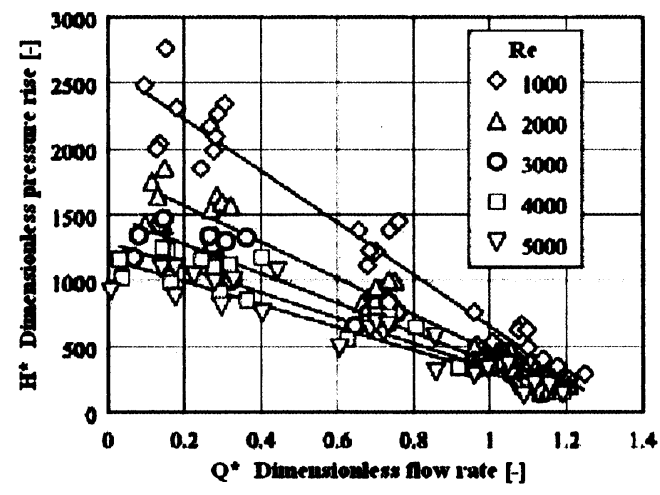

Fig. $7 \quad H-Q$ characteristics in dimensionless scales

であり, バルブ開度を変化させることで得たものであ る. 図 6 中の曲線は見やすいように実験点を低次多項 式で補間したものである。作動流体はメ夕ノールで, バルブ開度が $100 \%$ とき $n=1000 \mathrm{rpm}$ において流 量 $Q=2.6 \times 10^{-6} \mathrm{~m}^{3} / \mathrm{s}$ である. 図 6 より, 回転数が一 定の条件では流量 $Q$ の減少によって正味差圧 $H$ が増 加することがわかる。これは差圧の増大によって流量 が減少するというポンプの一般的下降特性に従うこと を意味する．これに対してモータの軸動力は流量が小 さいほど増大している.これは流量が小さいほど差圧 が大きいためであり, 軸動力が主として差圧に支配さ れるためである.ただし軸動力は差圧に対して完全に は比例しておらず, 微小流量の条件でさらに増大して いる.この結果, 動力効率 $\eta$ は流量が大きい条件のほ うが増加するというデータを示した. 微小流量の条件 で軸動力が余分に増大する理由は, 容積効率が零近く になるときにトロコイドギヤポンプ内部の流れがすべ てクリアランス部から漏れて内部循環するためであ る.このとき流体は 2 種類のクリアランス $\varepsilon$ と $\delta$ の 間を高速に逆流し, 大きなトルク負荷をもたらしてい ると考えられる。

$3 \cdot 3$ レイノルズ数の影響 本研究では, ポンプ の小形化をねらう開発研究のためレイノルズ数に対す るポンプ性能の把握を重視している.そこで図 7 のよ うにポンプの $H-Q$ 特性をレイノルズ数によって分類 してプロットした.ここで横軸は無次元流量, 縦軸は 無次元差圧である. 実験点はバルブ開度と回転数, な らびに流体の温度の三つを変化させてレイノルズ数別 にプロットした。この結果, 同じレイノルズ数の実験 点を結ぶと, 右下がりのほほ直線的な関係があること がわかる.また，レイノルズ数が小さいほどその直線 は上に移動し, 高い正味差圧 (=ポンプ昇圧)をもたら すことが確認できる.このことは, トロコイドギヤポ 


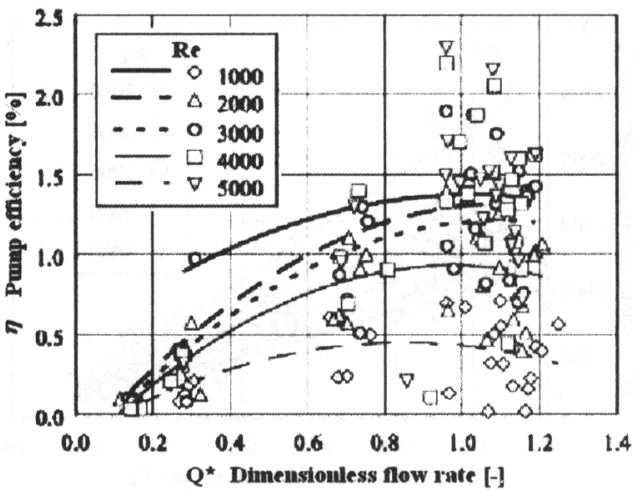

Fig. 8 Pump efficiency and dimensionless flow rate

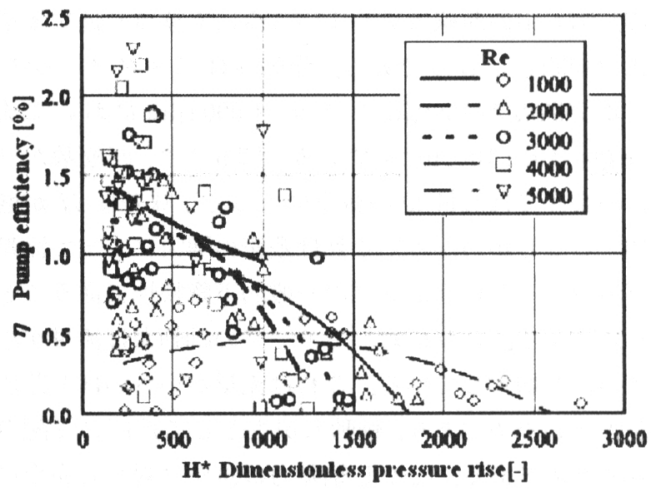

Fig. 9 Pump efficiency and dimensionless pressure rise

ンプの流体駆動機構が低レイノルズ数条件に適合して いる，すなわち粘性を活用したメカニズムを保有して いることを改めて裏付けるものである。ここで得られ たデータを最小二乗近似すると, レイノルズ数が Re $=1000 \sim 5000$ の範囲においては, 無次元差圧 $H^{*}$ が $R e^{-0.4}$ 乗に比例して減少することがわかった. なお無 次元流量は図 7 において $Q^{*}>1$ の範囲までデータが 分布している.これは式（4）の基準流量 $Q_{0}$ に対して 実際には約 20\%流量が大きい点で厳密な理論流量が 存在することを意味している。

次に図 8 に無次元流量を横軸としてポンプの動力効 率をプロットした。モータの軸動力に分散があるため レイノルズ数に対して明りょうにグルーピングできな い状態であるが, 最小二乗近似された補間曲線は少な くとも低レイノルズ数のほうが高い動力効率をもつこ とを示唆している. また動力効率 $\eta$ は無次元流量 $Q^{*}$ が大きいほど増大する。なおモー夕の軸動力に大きな 分散が生じる原因は, トロコイドギヤのかみ合わせや クリアランス部のわずかな形状の変化による.

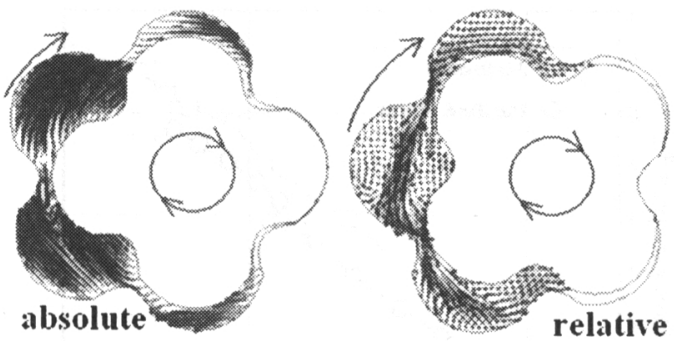

(a) $\operatorname{Re}=10$

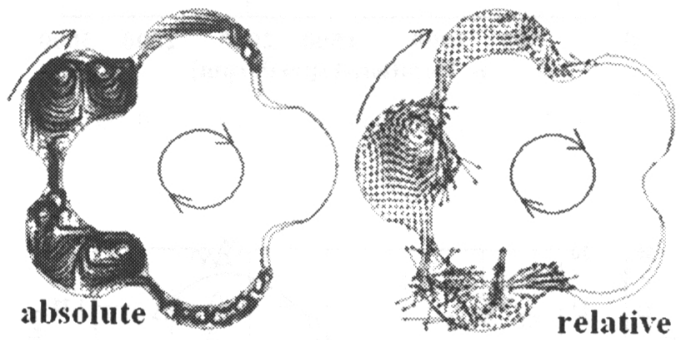

(b) $R e=1000$

Fig. 10 Internal flow structure obtained by $\mathrm{CFD}^{(1)}$

図 9 は, 無次元差圧を横軸として動力効率をプロッ トしたものである。全体として差圧が小さいほど動力 効率が高く, 差圧による逆流や漏れが少ないほうがよ いことを示している. 図 9 の上では, レイノルズ数に 対する影響は低差圧条件のみ比較可能であり,データ の分散が激しいものの，ここでも低レイノルズ数ほど 動力効率が高いことを示している.

$3 \cdot 4$ 内部流動との関係に関する考察 図 10 に三 次元数值解析によって得られたトロコイドギヤポンプ の内部流動を示す。この結果は既報(1) からの抜粋で ある. 各図の左側は流体の絶対速度による流線, 右側 はポンプの回転速度を差引いた流体のギヤ歯面に対す る相対速度ベクトルである、レイノルズ数が低い場合 $(R e=10)$ では, 流体は内外二つのギヤ歯面の絶対速 度を結ぶような速度分布となる。ただしクリアラシス 部からは噴流状の漏れが生じる。ただしこの噴流は容 積効率を低下させるものの, クリアランス部での差圧 を保持する役割があるためポンプの正味差压を著しく 低下させない.これに対してレイノルズ数が高い場合 $(R e=1000)$ では，二つのギヤの間で渦群が形成され， ギヤ表面でギヤの進行方向とは異なる流体の動きを含 む.またクリアランス部ではレイノルズ数が高い(粘 性が低い)ことで差圧が保持されにくくなる. 数值解 析では Re>1000の条件について結果は未取得であ るが, 今回の実験データのレイノルズ数依存性につい ては数值解析結果と定性的に一致する. 
$3 \cdot 5$ 動力効率に関する今後の課題 本研究では 低レイノルズ数であるほどポンプ性能が高いという予 測を実験的に確認することができた。しかしその一方 では, 小形化したトロコイドギヤポンプの動力効率 $\eta$ が最大でも約 $2 \%$ いないことが明らかとなった(図 6, 8〜9 の縦軸スケール参照). 一般にポンプを小形化 するとしゅう動部の摩擦損失が相対的に卓越し, 軸動 力の大半をそれにより消失することは事実である。し かし摩擦損失の絶対值も小形化によって縮小するた め, 動力効率はしばしば度外視されてきた。しかしこ の性質は低レイノルズ数で流体力学的に高性能という トロコイドギヤポンプの利点を阻害するものである. 今後, 低レイノルズ数においてクリアランス部での摩 擦が最小となるよう設計する必要がある.

今回利用したトロコイドギヤポンプでは, 六つのし ゆう動面における遠心クエット流れ，またはねじれク エット流れによるトルクの損失が生じ, 層流理論より 次の損失動力を伴う.

$$
L_{\delta}=\frac{\pi \mu}{\delta} \omega^{2} R^{4} \Lambda
$$

ここで $R$ は外側ギヤの外半径(ケーシングの半径)で, $\Lambda$ は次式による幾何学的定数である.

$$
\Lambda=\left(\frac{1}{2}+2 \frac{W}{R}\right)\left(\frac{k}{k+1}\right)^{2}-\frac{2 k+1}{2 k^{2}}\left(\frac{D}{2 R}\right)^{4}
$$

ここで $W$ はギヤ回転軸方向の幅である．損失動力は 式(15)のとおり $R^{4}$ と $\omega^{2}$ に比例し, 式(16)のとおり 歯数 $k$ が小さいほど低下する性質をもつ. 損失動力 と正味動力の比(以下, 損失比) は, 式 (2)，(4), (14)，（15）より次のように導かれる.

$$
\frac{L_{\delta}}{L}=\frac{\Lambda}{R e H^{*} Q^{* 2}} \frac{4(\pi R)^{4}}{\left(V_{o}-V_{i}\right) \delta}
$$

この式より, $R e$ 数の低下による損失動力割合の増加 は避けられないことが改めて確認される, 次に, 損失 比は $Q^{*}$ の二乗と $\delta$ の積に反比例することに注意し たい.クリアランス $\delta$ は大きいほど損失比を低下さ せるが, 実際には容積効率の低下を同時にもたらし, その結果, 二乗で効いて損失比がむしろ増加する可能 性がある.またそのときの容積効率の低下の度合いは 差圧 $H^{*}$ に依存しており, 全体として $\delta, Q^{*}, H^{*}$ の三 つの変数が相互にどのように振る舞うかで決定され る.また, 幾何学的構造だけでいえば, 損失比はケー シング半径 $R$ の 4 乗に比例していることから, 流体 封入体積 $\left(V_{0}-V_{1}\right)$ に対して可能な限り $R$ を減らすこ とが重要であるといえる。

なお，今回利用したポンプでは $\Lambda=0.825 て ゙ あ り ，$ 式(17)に実験值を代数すると, クリアランス $\delta$ の平均
值は $\delta=23 \mu \mathrm{m}$ と計算される.これは内側ギヤの転円 半径の $2.3 \%$ のリアランスが存在することを意味す る. 今後, クリアランス $\delta$ をパラメータとしてさらに 詳細解析を実施する予定である。

\section{4. ま と め}

内接形トロコイドギヤポンプを小形化し, $R e<$ 5000 の低レイノルズ数条件におけるポンプ性能を実 験的に研究した.この結果, 数値解析による予測結果 に対して定性的に一致する性能が確認された.すなわ ちポンプ駆動部がもたらす昇圧はレイノルズ数が低い ほど高い。これと同時に容積効率ならびに動力効率も レイノルズ数が低い場合のほうが高い. 低レイノルズ 数での良好な性能は, レイノルズ数の定義のとおり, 粘度が高い条件, サイズが小さい条件, 回転数が小さ い条件で有利であることを意味する。本研究ではポン プの小形化を目的としており, その観点で解釈すれば, トロコイドギヤポンプが小形化に適した機構をもって いるといえる. なお, 既報(1) で述べた, さらに低いレ イノルズ数の条件での数值計算結果は, ギヤ表面での 粘性せん断応力が流体を順方向に駆動するというもの であった(これは他の容積形ポンプには見受けられな い性質である).今後, 本実験よりもさらに低レイノ ルズ数での実験データを取得し, このことを検定する 必要がある。

一方，ポンプの小形化にあたっては上記のレイノル ズ数だけではなく, シーリング, クリアランス, トロ コイドギヤ歯面形状の加工精度など, 有次元での技術 的な制約にも支配される. 本研究ではしゅう動摩擦の 大きなポンプシール等を利用していないにもかかわら ず, 動力効率の值は最大でも $2 \%$ 程度であり, 軸動力 のほとんどがしゅう動部で損失することがわかった. これはしゅう動部のかんげきを占める流体層の粘性せ ん断応力がポンプ正味の作用を卓越することによる. 動力効率の改善のためには, しゅう動部のクリアラン ス $\delta$ 最適值を検討しなければならない.ただし， $\delta$ の変化はポンプ性能としゅう動部損失に対して互いに 相反する影響を与えるため, さらなる詳細解析が必要 である。

実験の遂行にあたり福井県工業技術センター創造研 究部 芦原氏, 松井氏, 青柳氏, ならびに福井大学学 部生 上村君(現アラコ(株)), 大学院生 上埜君(現 ダイキン工業(株))の協力を得たことについて深く謝 意を示す。 


\section{文献}

（1）村井祐一・宮城直樹・宮崎孝司・山本富士夫，低レイ， ルズ数域における内接形トロコイドギヤポンプの内部流 動(3 次元数值シミュレーションによるポンプ特性の評 価), 機論, 70-695, B(2004), 1754-1761.

（2）大橋秀雄・黒川淳一・ほか 8 名, 流体機械ハンドブック (1.6 容積型ポンプの形式と構造), (2002), 157-167, 朝倉 書店.
（3）井上雅弘・鎌田好久，流体機械の基礎，(1997)，29-31，コ ロナ社.

(4) Shung, J. B., Pennock, G. R., The direct contact problem in a trochoidal-type machine, Mech. Mach. Theory, 29 (1994), 673-689.

(5) Ranganathan, G., Raj. H.S. T. and Ram, P. V. M., Wear characterisation of small PM rotors and oil pump bearings, Tribol. Int, 37 (2004), 1-9.

（6）日本機械学会編，機械工学便覧基礎編，A 5 流体工学, (1986), 76-78. 